\title{
DEVELOPMENT AND VALIDATION OF NOVEL RP-UHPLC/ DAD METHODS FOR SIMULTANEOUS QUANTIFICATION OF REMOGLIFLOZIN AND METFORMIN IN BULK AND FORMULATION
}

\author{
V. A. Patel ${ }^{1, \bowtie}$, C. V. Pandya ${ }^{1}$, Z. J. Patel ${ }^{1}$, D. R. Patel ${ }^{1}$ and A. C. Pandya ${ }^{2}$ \\ ${ }^{1}$ Department of Chemistry, HVHP Institute of P. G. Studies and Research, Kadi, \\ KSV- Gujarat- 382715 India \\ ${ }^{2}$ Department of Microbiology, School of Sciences, P P Savani University- Gujarat-394125 India \\ ${ }^{\square}$ Corresponding Author: viral4chem@gmail.com
}

\begin{abstract}
For the treatment of diabetes mellitus, a new formulation containing remogliflozin etabonate (REMO) and metformin $\mathrm{HCl}$ (MET) has recently been approved. This study is aimed to develop simple and quick RP-UHPLC methods for measuring REMO and MET simultaneously. REMO and MET chromatographic separation were carried out on a Zorbax Eclipse Plus C18 $(150 \times 4.6 \mathrm{~mm}, 5 \mu \mathrm{m})$ column with acetonitrile: phosphate buffer $(\mathrm{pH}: 3)(60: 40 \%$, $\mathrm{v} / \mathrm{v}$ ) mobile phase, $10 \mu \mathrm{l}$ sample volume and $1.0 \mathrm{ml} / \mathrm{min}$ flow rate at $230 \mathrm{~nm}$ in a diode array detector. REMO had a $99.51 \%$ average percent assay, while MET had a $99.60 \%$ average percent assay. The methods projected were simple, precise, accurate, and fast. They can also be used to verify the consistency of REMO and MET formulations regularly.
\end{abstract}

Keywords: Metformin, Remogliflozin, UHPLC, Method Development, Validation, Degradation

RASĀYAN J. Chem., Vol. 14, No.2, 2021

\section{INTRODUCTION}

A new formulation for the management of diabetes mellitus containing metformin $\mathrm{HCl}$ (MET) and remogliflozin etabonate (REMO) was recently approved. Diabetes mellitus is the leading cause of mortality worldwide. ${ }^{1}$ Therefore, to mitigate diabetic problems such as kidney disease, retinopathy, neuropathy, cardiovascular complications, etc., improved glycemic control is necessary. ${ }^{2}$ Combination therapy with antidiabetic drugs with different modes of action is commonly recommended over prophylaxis to reach the desired therapy goal and to reduce the side effects. ${ }^{3}$ For the treatment of diabetes mellitus, a new product containing metformin $\mathrm{HCl}$ and remogliflozin etabonate has recently been introduced. Metformin HCl (MET, Fig.-1 (a)) is commonly used as an oral hypoglycemic agent with several different mechanisms of action, which decreases hepatic glucose production by increasing anaerobic glucose metabolism in enterocytes, reducing insulin sensitivity and hepatic gluconeogenesis, thus swelling glucose consumption by peripheral cells ${ }^{4}$. Remogliflozin etabonate (REMO, Fig.-1 (b)) is a newly discovered oral hypoglycemic agent which is insulin-independent ${ }^{5}$. It functions by inhibiting cotransporter-2 sodium-glucose (SGLT2), an essential enzyme for the intestinal absorption of sugar in the kidneys, thus increasing the reduction of urinary sugar. SGLT-2 antagonists have many positive effects, aside from glycemic regulation, including increased body weight, decreasing blood pressure, and lowering levels of hemoglobin A1c. Therefore, when co-administered with REMO and MET, is more helpful, especially in patients with heart and kidney disease that need more reductions in hemoglobin A1c levels. ${ }^{6-8}$ The literature provides several analytical approaches for the quantitative analysis of metformin alone in both formulations and biological samples using spectrophotometric ${ }^{9}, \mathrm{HPLC}^{10}, \mathrm{LCMS}^{11}$, capillary electrophoresis ${ }^{12}$. Metformin was also quantified with spectrophotometric ${ }^{13}$, HPLC $^{14-18}$, LCMS $^{19}$ in conjunction with other antidiabetic medicines. Metformin, along with canagliflozin ${ }^{20}$ and empagliflozin ${ }^{21}$, was also considered by the HPLC process. 
RASĀYAN J. Chem.

Vol. 14 | No. 2 |1384-1393| April - June | 2021

Reported quantification of REMO from bulk and in-house tablets using a spectroscopic approach ${ }^{22}$ and high-performance thin-layer chromatography ${ }^{23}$, used the LC / MS method for plasma REMO quantification. UPLC was recently used to publish an analytical method for the simultaneous determination of REMO and MET from formulation. ${ }^{24}$ In parallel, this research aimed to develop a simple, environmentally friendly UHPLC technique, using solutions prepared in the laboratory and developed as an internal standard for the simultaneous quantification of REMO and MET.

As a result, the second-derivative UHPLC analysis was used to measure REMO and MET simultaneously through separating or differentiating materials from the composition. According to ICH guidelines, the pharmaceutical industry usages consistency by proposal methodology to create a fast and cost-effective RP-UHPLC process.<smiles>CN(C)C(=N)NC(N)N</smiles>

(a)

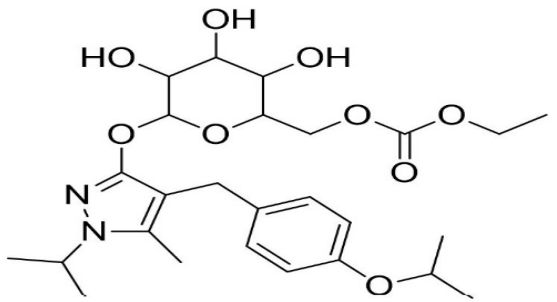

(b)

Fig.-1: Chemical Structure of (a) Metformin (b) Remogliflozin

\section{EXPERIMENTAL}

\section{Instruments}

The RP-UHPLC method was developed using the Agilent UHPLC (CA, USA) and was attached to the autosampler G4226A, quaternary pump G4204A, thermostat G1330B, TCC (thermostat column compartment) G1316C and DAD (diode array detector) G4212A. To track the signals, Agilent software was used for the OpenLAB CDS Chem station (version A.01.05).

\section{Materials and Chemicals Used}

API (active pharmaceutical ingredients) of remogliflozin etabonate and metformin hydrochloride were obtained from Glenmark Pharmaceuticals, Maharashtra, India. Remo-Zen M 500 (REMO100 mg and MET $500 \mathrm{mg}$ tablets, Glenmark Pharmaceuticals Gujarat, India) obtained from a local pharmacy. HPLC grade water and acetonitrile were obtained from SDFCL (Ahmedabad, India). Orthophosphoric acid and potassium dihydrogen phosphate were obtained from Finar Limited (Ahmedabad, India).

\section{Preparation of Standard Solutions}

Accurately weighed REMO and MET was dissolved in the mobile phase to achieve a concentration of $500 \mu \mathrm{g} / \mathrm{mL}$. Furthermore, by diluting REMO and MET; working standards and laboratory mixed solutions for UHPLC methods with mobile phase, working standards and laboratory mixed solutions for UHPLC methods were developed.

\section{Preparation of Sample Solutions}

Using a mortar pestle and fine particle size, ten Remo-Zen M 500 tablets were accurately weighed and powdered. Weighted tablet powder containing $100 \mathrm{mg}$ REMO and $500 \mathrm{mg}$ MET was then transferred to a $100 \mathrm{~mL}$ volumetric flask containing $50 \mathrm{~mL}$ mobile phase. The flask was properly mixed to dissolve the drugs using sonication. The solutions were then transferred into other volumetric flasks, and the finishing volume was reached using the mobile phase. The final concentrations of REMO and MET were $50 \mu \mathrm{g} / \mathrm{mL}$ and $50 \mu \mathrm{g} / \mathrm{mL}$, respectively.

\section{Chromatographic Conditions}

REMO and MET were chromatographic separated using an Agilent Zorbax Eclipse Plus C18 $(150 \times 4.6$ $\mathrm{mm}, 5 \mu \mathrm{m})(\mathrm{CA}, \mathrm{USA})$ column with isocratic mode. The mobile phase used to separate the analytes was a $70: 30(\mathrm{v} / \mathrm{v})$ mixture of acetonitrile and $30 \mathrm{mM}$ potassium dihydrogen phosphate ( $\mathrm{pH}$ adjusted to 4.0 with OPA (orthophosphoric acid)). At a temperature of $30^{\circ} \mathrm{C}$, the mobile phase was pumped at a rate of 1 
RASĀYAN J. Chem.

Vol. 14 | No. 2 |1384-1393| April - June | 2021

$\mathrm{mL} / \mathrm{min}$. The chromatogram was created by using a diode array detector at $245 \mathrm{~nm}$ to measure the UV absorbance of the eluted analytes. For the investigation, the injection volume of the auto-sampler was set to $5 \mu \mathrm{L}$.

\section{Method Validation}

To show that the proposed methods are acceptable for quality management, the existing analytical methods must be tested under the ICH guidelines. The validation of the proposed techniques ${ }^{25}$ for linearity, quantification limit, detection limit, accuracy and precision were carried out. Additionally, for device suitability and robustness, the UHPLC approach was also validated.

\section{System Suitability}

The system suitability evaluation of the UHPLC method was assessed by analyzing $50 \mu \mathrm{g} / \mathrm{mL}$ of REMO and MET solutions while maintaining the standard concentration at $50 \mu \mathrm{g} / \mathrm{mL}$. Peak area, tailing factor, theoretical plate, retention time, and resolution where the different parameters were determined in triplicate.

\section{Linearity}

Nine concentrations range from 20 to $100 \mu \mathrm{g} / \mathrm{mL}(20,30,40,50,60,70,80,90$ and $100 \mu \mathrm{g} / \mathrm{mL})$ were transferred to the vial series with the necessary amounts of REMO and MET. Chromatographs were recorded by injecting $5 \mu \mathrm{L}$ of each triplicate sample. The calibration curves were created using the REMO and MET peak area ratios calculated from a chromatogram and the related REMO and MET concentrations.

\section{LOD and LOQ}

The limit of detection (LOD) and limit of quantification (LOQ) demonstrates the high sensitivity of the analytical methods. As a result, LOD and LOQ were calculated for all the methods via the $3.3 \mathrm{~d} / \mathrm{s}$ and 10 $\mathrm{d} / \mathrm{s}$ formulas, respectively, where "d" (standard deviation of the response intercept) and "s" (slope of the standardization curve).

\section{Precision}

The precision of both the analytical approaches was measured in terms of interday and intraday precision. To determine the inter-day precision, six different REMO and MET solutions were tested in triplicates on the same day, covering the entire calibration range. On two consecutive days, the above-prepared solutions were analyzed for intraday precision. The method's high precision has been described as relative standard deviation (RSD).

\section{Accuracy}

For this previously tested sample solution containing a known amount of REMO and MET, the recovery of the suggested method was checked by the placebo spiking process with three distinct concentration ranges of 50 percent, 100 percent and 150 percent. To determine the percent recovery and percent relative error, triplicate assessments of these three levels have been reported.

\section{Robustness}

During the chromatographic conditions, intentional minute changes were made, such as mobile phase $\mathrm{pH}$ (2.8 and 3.2), wavelength $(228 \mathrm{~nm}$ and $232 \mathrm{~nm})$, temperature $\left(25^{\circ} \mathrm{C}\right.$ and $\left.35^{\circ} \mathrm{C}\right)$ and flow rate $(1.8$ $\mathrm{mL} / \mathrm{min}, 2 \mathrm{~mL} / \mathrm{min}$ and $2.2 \mathrm{~mL} / \mathrm{min}$ ). REMO and MET peak area ratios were the responses that were scrutinized.

\section{Forced Degradation Study}

To demonstrate the development method of stability indicating method, the formulation sample was subjected to acid, base, thermal, photo, and peroxide degradation to detect degradants in the chromatogram. By adding $2 \mathrm{ml}$ of $1 \mathrm{~N} \mathrm{HCl}$, maintained for 2 hours at $60^{\circ} \mathrm{C}$, acid degradation was carried out and stress was neutralized with $\mathrm{NaOH}$ and diluted with the mobile phase. Similarly, $2 \mathrm{ml}$ of $1 \mathrm{~N}$ $\mathrm{NaOH}$ was maintained at $60^{\circ} \mathrm{C}$ for 2 hours and stress was neutralized by HCL and diluted with the mobile 
RASĀYAN J. Chem.

Vol. 14 | No. 2 |1384-1393| April - June | 2021

phase. $\mathrm{H}_{2} \mathrm{O}_{2}(3 \%)$ was applied at $60^{\circ} \mathrm{C}$ for peroxide degradation for 2 hours and the stressed sample was diluted with the mobile phase. The sample was exposed to heat at $60^{\circ} \mathrm{C}$ for 2 hours in thermal degradation and organized the sample according to the assay process, exposed to UV light with an intensity of $365 \mathrm{~nm}$ for six hours in photodegradation, and prepared the sample according to the assay procedure.

\section{RESULTS AND DISCUSSION}

\section{Method Optimization of Chromatographic Conditions}

The main aim was to define a simple stability-indicating method with the optimum resolution by UHPLC for estimating REMO and MET simultaneously. In quality control laboratories, simple RP-UHPLC methods are favored to achieve reproducibility and accurate outcomes in a short period. The chromatographic method has been improved by modifying different parameters, such as the $\mathrm{pH}$, mobile phase, buffer and organic modifier used in the mobile phase and the mobile phase configuration. Multiple mobile phases were checked between two drugs before a good resolution was achieved. With acetonitrile and $20 \mathrm{mM}$ potassium dihydrogen phosphate buffer $(\mathrm{pH} 3)$ in 70:30, 60:40, 50:50, 40:60, and 45:55 (v/v) proportions, the Eclipse Plus C18 $(150 \times 4.6 \mathrm{~mm}, 5 \mu \mathrm{m})$ column was tested as a mobile phase. The drug's peak shape was poor, and break peaks were observed alongside the REMO peak $(60: 40 \mathrm{v} / \mathrm{v}$ Buffer: $\mathrm{ACN}$ ), indicating that increasing the organic modifier's composition decreased the retention time. The method was optimized with acetonitrile and phosphate buffer 60:40 (v/v) mobile phase composition. Buffers Molarity of 30, 20 and $10 \mathrm{mM}$ is tested. With the change in buffer molarity, there were no major improvements in chromatographic reaction and peak form. For further study, buffer molarity of $10 \mathrm{mM}$ was chosen.

The method was configured as a mixture of acetonitrile and potassium dihydrogen phosphate buffer 10 $\mathrm{mM}(\mathrm{pH} 3.00)(60: 40 \mathrm{v} / \mathrm{v})$ after many experiments, at $1 \mathrm{~mL} / \mathrm{min}$ flow rate and $230 \mathrm{~nm}$ UV detection for a runtime of 6 minutes. The satisfactory resolution, retention time and tailing factor for REMO and MET were obtained by these chromatographic conditions. This chromatogram of REMO and MET is represented in (Fig.-2).

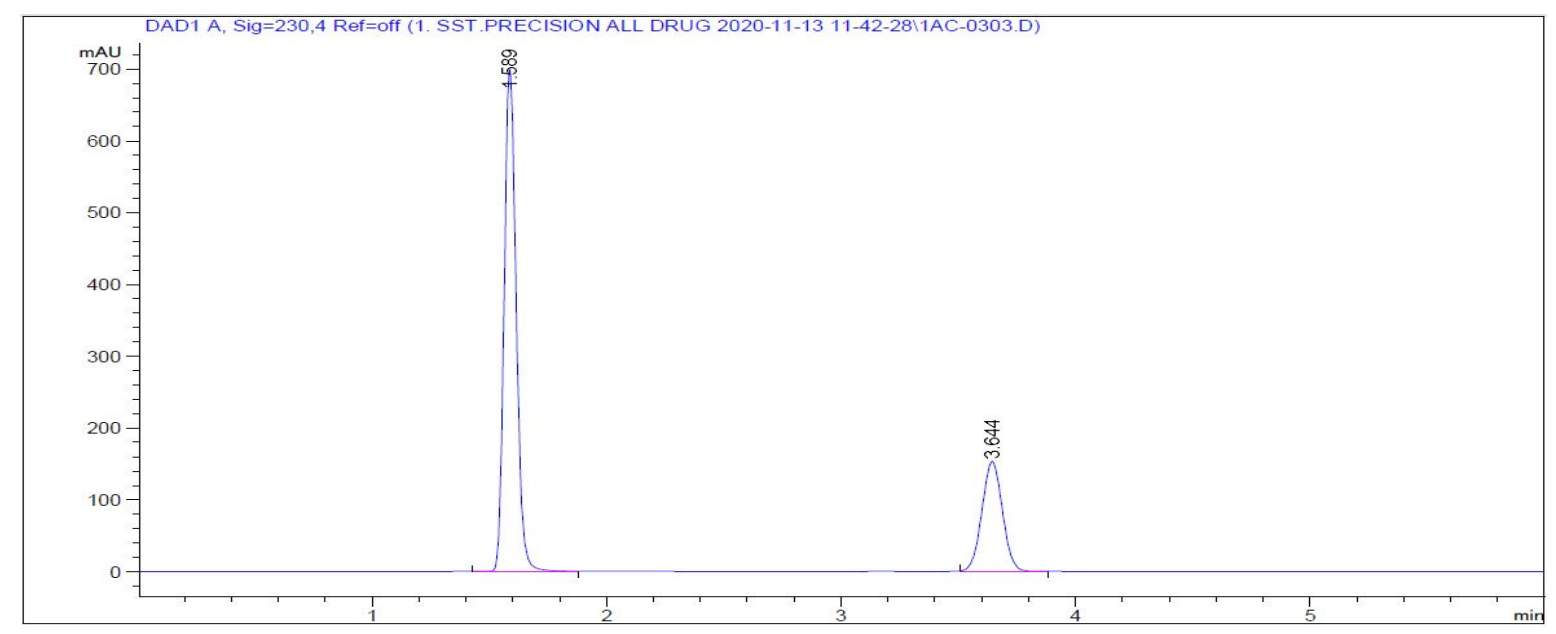

\section{System Suitability}

Fig.-2: UHPLC Chromatogram for REMO and MET Standard

As per standard guidelines, determining system suitability parameters is a part of the development of chromatographic methods. (Table-1) reports the determined retention time, resolution, theoretical plate, and symmetry factor.

Table-1: REMO and MET System Suitability Results

\begin{tabular}{c|c|c}
\hline Constraints & REMO & MET \\
\hline Peak area (mAs) & $937.73 \pm 7.39$ & $2502.72 \pm 27.87$ \\
\hline RSD (\%) & 0.79 & 1.11 \\
\hline Retention time (min) & 3.65 & 1.59 \\
\hline Symmetry factor & 0.94 & 0.90 \\
\hline Theoretical plates & 8209 & 4433 \\
\hline \multicolumn{3}{|c}{1387}
\end{tabular}


RASĀYAN J. Chem.

Vol. 14 | No. 2 |1384-1393| April - June | 2021

\section{Linearity and Range}

\begin{tabular}{c|c|c}
\hline Resolution & 16 & - \\
\hline Retention factor $\mathrm{K}^{\prime}$ & 6.32 & 2.19 \\
\hline
\end{tabular}

The standard graph was constructed covering a concentration range of $10-100 \mu \mathrm{g} / \mathrm{mL}$. At each concentration, three separate determinations were performed. With a correlation coefficient of 0.999 REMO and 0.999 MET, the detector's reaction was found to be linear. The regression equations of $\mathrm{y}=$ $21.047 \mathrm{x}-0.274$ (for REMO) and $\mathrm{y}=54.524 \mathrm{x}+10.275$ (for MET) shown in (Table-2) and (Fig.-3), are the standard calibration curves.

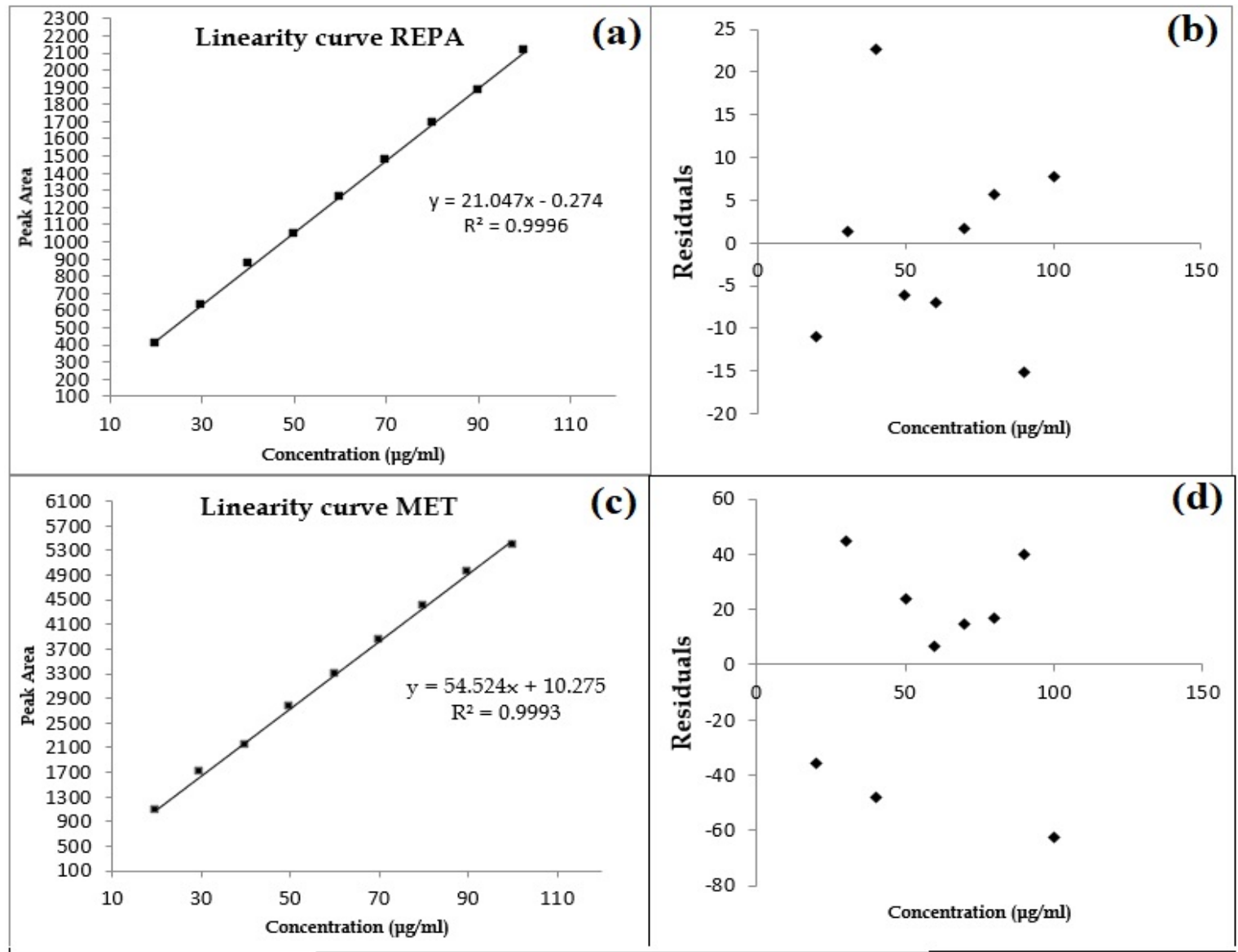

Fig.-3: Linearity Plot of (a) REMO and (b) its corresponding residual plot; Linearity Plot of (c) MET and (d) its corresponding Residual Plot

Table-2: Calibration Constraints Results for REMO and MET

\begin{tabular}{c|c|c}
\hline Linearity Constraint & REMO & MET \\
\hline Range $\left(\mu \mathrm{g} \mathrm{mL} \mathrm{mL}^{-1}\right)$ & $20-100$ & $20-100$ \\
\hline Slope & 21.047 & 54.52 \\
\hline Intercept & 0.274 & 10.28 \\
\hline Regression coefficient $\left(\mathrm{r}^{2}\right)$ & 0.9996 & 0.9993 \\
\hline Standard error of Intercept & 10.35 & 35.09 \\
\hline Standard deviation of intercept & 31.05 & 105.28 \\
\hline Confidence limit of the slope & $20.81 \pm 2.44$ & $54.63 \pm 1.21$ \\
\hline Confidence limit of the intercept & $0.28 \pm 0.15$ & $08.68 \pm 1.85$ \\
\hline
\end{tabular}

\section{LOD and LOQ}

The standard deviation of the response and the slopes of the three calibration curves were used to calculate the LOD and LOQ. The results of (Table-3) low LOD and LOQ for both analytes, indicate the high sensitivity of both the analytical procedures. 
RASĀYAN J. Chem.

Vol. 14 | No. 2 |1384-1393| April - June | 2021

Table-3: The Results of LOD and LOQ

\section{Precision}

\begin{tabular}{c|c|c}
\multicolumn{3}{c}{ Table-3: The Results of LOD and LOQ } \\
\hline Drug & LOD $\left(\mu \mathrm{g} \mathrm{mL}^{-1}\right)$ & LOQ $\left(\mu \mathrm{gL}^{-1}\right)$ \\
\hline REMO & 1.47 & 4.92 \\
\hline MET & 1.93 & 6.44 \\
\hline
\end{tabular}

Testing six different concentrations of all analytes on the same day and two days later yields interday and intraday precision. The percentage RSD for REMO (0.72-0.84) and MET (0.63-0.92) in (Table-4) was found to be within the range, indicating high precision of the UHPLC methods.

Table-4: Precision results for REMO and MET

\begin{tabular}{c|c|c|c|c}
\hline Analysis Data & \multicolumn{2}{|c|}{ Intraday } & \multicolumn{2}{c}{ Interday } \\
\hline Assay & REMO & MET & REMO & MET \\
\hline Assay Mean (\%) & 101.25 & 100.52 & 100.47 & 100.81 \\
\hline RSD (\%) & 0.72 & 0.63 & 0.84 & 0.92 \\
\hline
\end{tabular}

\section{Accuracy}

By evaluating three different degrees of concentration $(50 \%, 100 \%$, and $150 \%)$ and measuring the $\%$ Recovery and \% RE, a recovery analysis was analyzed. The outcomes (Table-5) are presented as a mean recovery of $100.31 \%$ for REMO and $100.29 \%$ for MET using the process. For methods showing the high recovery of the analytical approaches, the $\% \mathrm{RE}$ was also found to be below \pm 2 percent.

Table-5: Accuracy Results for REMO and MET

\begin{tabular}{c|c|c|c|c}
\hline Drug & \% Replicated Dosage Nominal & Mean $(\%)(\mathrm{n}=3)$ & RSD (\%) & RE (\%) \\
\hline REMO & 50 & $99.72 \pm 0.62$ & 0.62 & -0.28 \\
\hline MET & 50 & $100.16 \pm 0.36$ & 0.36 & 0.16 \\
\hline REMO & 100 & $101.52 \pm 0.55$ & 0.54 & 1.52 \\
\hline MET & 100 & $101.29 \pm 0.45$ & 0.45 & 1.29 \\
\hline REMO & 150 & $99.67 \pm 0.70$ & 0.7 & -0.33 \\
\hline MET & 150 & $99.41 \pm 0.18$ & 0.18 & -0.59 \\
\hline
\end{tabular}

\section{Study of Tablets Formulations}

In the analysis of REMO and MET in the preparation of marketed tablets, the approach developed has been successfully applied. For the simultaneous quantification of REMO and MET from the Marketed tablet study (Remo-Zen M 500, Glenmark Pharmaceuticals), optimized UHPLC methods were used (Fig.4). The percent assay was found to be $99.8-101.7 \%$ for REMO and $99.8-101.4 \%$ for MET; and are tabulated in (Table-6).

\begin{tabular}{|c|c|c|c|c|c|c|c|c|c|c|}
\hline \multirow{2}{*}{$\begin{array}{l}\text { Tablet (Remo- } \\
\text { Zen M 500) } \\
\text { Replicate } \\
\text { number } \\
\end{array}$} & \multicolumn{2}{|c|}{ Retention time } & \multicolumn{2}{|c|}{ Area } & \multicolumn{2}{|c|}{ Symmetry } & \multicolumn{2}{|c|}{$\begin{array}{c}\text { Theoretical } \\
\text { plates }\end{array}$} & \multicolumn{2}{|c|}{ \% Assay } \\
\hline & REMO & MET & REMO & MET & REMO & MET & REMO & MET & REMO & MET \\
\hline 1 & 3.537 & 1.545 & 928 & 2533 & 0.97 & 0.91 & 8293 & 4276 & 101.6 & 99.8 \\
\hline 2 & 3.573 & 1.542 & 973 & 2530 & 0.97 & 0.91 & 8221 & 4293 & 100.4 & 100.9 \\
\hline 3 & 3.573 & 1.538 & 953 & 2524 & 0.97 & 0.89 & 8221 & 4237 & 101.7 & 100.8 \\
\hline 4 & 3.534 & 1.528 & 949 & 2511 & 0.95 & 0.91 & 8165 & 4239 & 101.4 & 100.2 \\
\hline 5 & 3.558 & 1.529 & 954 & 2512 & 0.95 & 0.92 & 8245 & 4241 & 100.1 & 101.4 \\
\hline 6 & 3.542 & 1.529 & 953 & 2512 & 0.96 & 0.92 & 8189 & 4228 & 99.8 & 100.9 \\
\hline Mean \pm SD & $\begin{array}{c}3.553 \pm \\
0.02\end{array}$ & $\begin{array}{c}1.535 \pm \\
0.01\end{array}$ & $\begin{array}{l}951 \pm \\
14.32\end{array}$ & $\begin{array}{c}2520 \pm \\
9.86\end{array}$ & $\begin{array}{c}0.96 \pm \\
0.01\end{array}$ & $\begin{array}{c}0.91 \pm \\
0.01\end{array}$ & $\begin{array}{l}8222 \pm \\
44.52\end{array}$ & $\begin{array}{l}4252 \pm \\
25.87\end{array}$ & $\begin{array}{c}100.86 \pm \\
0.82\end{array}$ & $\begin{array}{c}100.67 \pm \\
0.58\end{array}$ \\
\hline$\% \mathrm{RSD}$ & 0.50 & 0.49 & 1.50 & 0.39 & 1.02 & 1.20 & 0.54 & 0.61 & 0.81 & 0.58 \\
\hline
\end{tabular}

\section{Robustness}

To determine the impact of minor changes in the experimental condition on the obtained results, a robustness test should be done according to $\mathrm{ICH}$. The mobile phase $\mathrm{pH}$, wavelength, temperature and flow rate are the four major factors to be considered. By adding the different conditions that maintain the robustness of the described method; retention time, symmetrical factors and theoretical plates have not 
RASĀYAN J. Chem.

Vol. 14 | No. 2 |1384-1393| April - June | 2021

changed significantly. Under various conditions, the retention time, symmetric factors and theoretical plates are tabulated (Table-7).
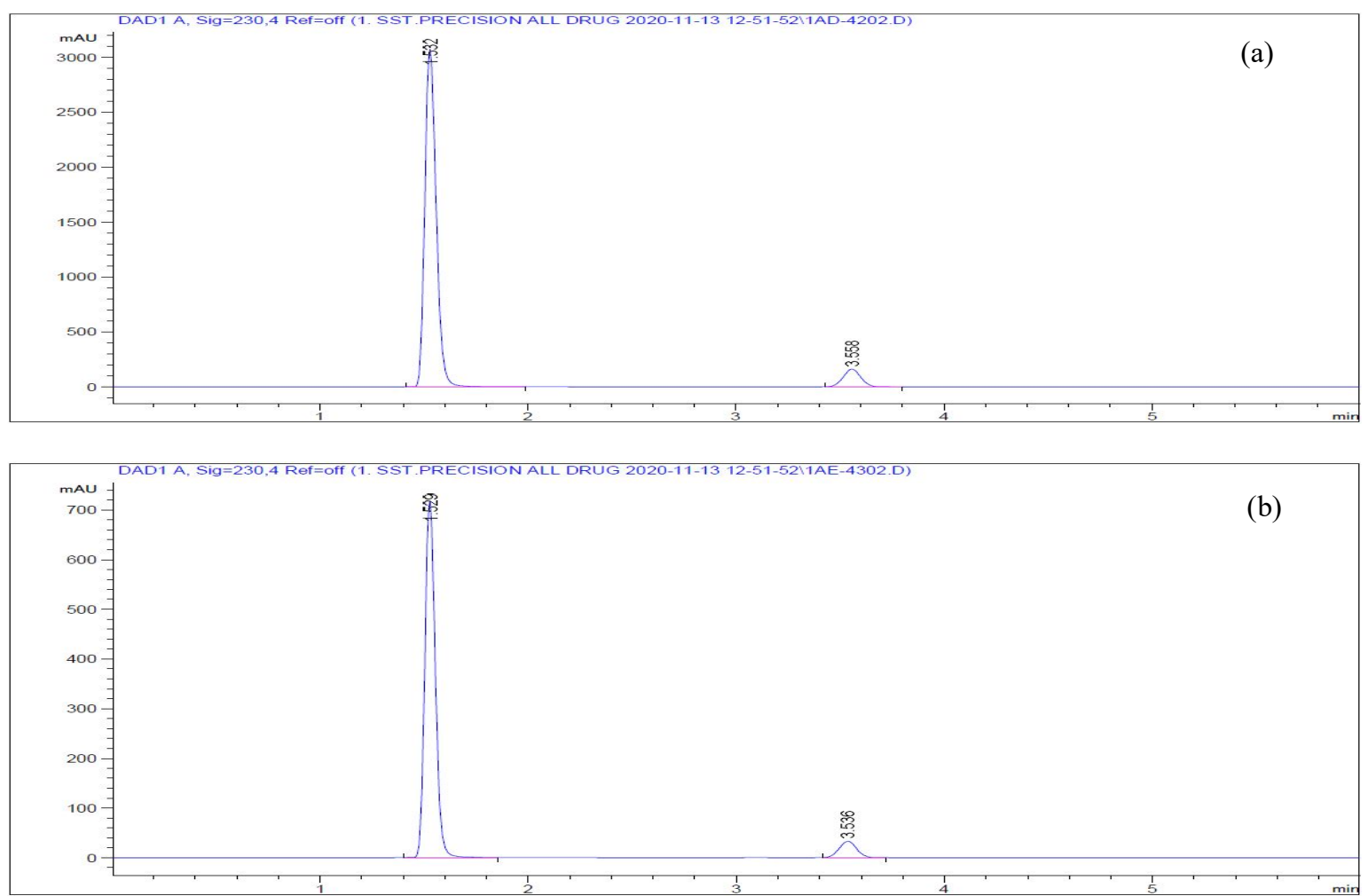

Fig.-4: Remo-Zen M 500 Capsule Sample Solution UHPLC Chromatogram of (a) REMO for $50 \mu \mathrm{gmL}^{-1}$ and (b) MET for $50 \mu \mathrm{gmL}^{-1}$

Table-7: Robustness Results for REMO and MET

\begin{tabular}{|c|c|c|c|c|c|c|c|c|c|}
\hline \multirow{2}{*}{ Constraint } & \multirow[t]{2}{*}{ Conditions } & \multicolumn{2}{|c|}{$\operatorname{RSD}(\%)(n=3)$} & \multicolumn{2}{|c|}{$\begin{array}{l}\text { Retention Time } \\
\text { (min) }\end{array}$} & \multicolumn{2}{|c|}{$\begin{array}{c}\text { Theoretical } \\
\text { Plates }\end{array}$} & \multicolumn{2}{|c|}{ Symmetric Factor } \\
\hline & & REMO & MET & REMO & MET & REMO & MET & REMO & MET \\
\hline \multirow{2}{*}{$\begin{array}{c}\text { Change in } \lambda_{\max } \\
230 \pm 5 \mathrm{~nm}\end{array}$} & 225 & 0.08 & 0.06 & 3.56 & 1.54 & 8147 & 4327 & 0.94 & 0.93 \\
\hline & 235 & 0.2 & 0.05 & 3.56 & 1.54 & 8073 & 4301 & 0.95 & 0.85 \\
\hline \multirow{2}{*}{$\begin{array}{l}\text { Change in flow } \\
\text { rate } 1 \pm 2 \mathrm{~mL} / \mathrm{min}\end{array}$} & 0.8 & 0.08 & 0.04 & 4.74 & 2.03 & 9774 & 5521 & 0.93 & 0.89 \\
\hline & 1.2 & 0.15 & 0.21 & 2.89 & 1.24 & 7123 & 3324 & 0.95 & 0.93 \\
\hline \multirow{2}{*}{$\begin{array}{c}\text { Change in Temp. } \\
30 \pm 5^{\circ} \mathrm{C}\end{array}$} & 25 & 0.2 & 0.25 & 3.57 & 1.55 & 8120 & 4327 & 0.95 & 0.82 \\
\hline & 35 & 0.62 & 0.41 & 3.59 & 1.54 & 8084 & 4226 & 0.94 & 0.86 \\
\hline \multirow{2}{*}{$\begin{array}{c}\text { Change in } \mathrm{pH} \\
3.0 \pm 2\end{array}$} & 2.98 & 0.13 & 0.24 & 3.54 & 1.52 & 8151 & 4283 & 0.93 & 0.88 \\
\hline & 3.02 & 0.17 & 0.19 & 3.79 & 1.49 & 8153 & 4048 & 0.93 & 0.86 \\
\hline
\end{tabular}

\section{Forced Degradation Study}

The conclusions have been considered satisfactory. Stability showing acid degradation, base degradation, peroxide stress condition, thermal degradation and light degradation as seen in (Fig.-5a, b, c, d and e) are demonstrated to illustrate the process. Peak retention time, REMO and MET recovery percentage of deterioration reached under various stress conditions are reported in (Tables-8 and 9).

Table-8: Degradation Result of REMO

\begin{tabular}{c|c|c|c|c|c}
\hline S. No. & Condition & $\mathrm{Rt}$ & Recovery \pm SD & \%RSD & $\%$ Drug Degraded \\
\hline 1 & Acid hydrolysis & 4.41 & $83.44 \pm 0.72$ & 0.86 & $16.12 \%$ \\
\hline 2 & Base hydrolysis & 3.62 & $75.28 \pm 0.48$ & 0.64 & $23.93 \%$ \\
\hline 3 & Oxidative degradation & 3.44 & $80.39 \pm 0.58$ & 0.72 & $18.57 \%$ \\
\hline 4 & Thermal degradation & 3.45 & $94.95 \pm 0.62$ & 0.65 & $4.80 \%$ \\
\hline 5 & Photo degradation & 3.43 & $97.37 \pm 0.47$ & 0.49 & $2.29 \%$ \\
\hline
\end{tabular}


RASĀYAN J. Chem.

Vol. 14 | No. 2 |1384-1393| April - June | 2021

Table-9: degradation result of MET

\begin{tabular}{c|l|c|c|c|c}
\hline S. No. & \multicolumn{1}{|c|}{ Condition } & Rt & Recovery \pm SD & \%RSD & $\%$ Drug Degraded \\
\hline 1 & Acid hydrolysis & 1.47 & $85.26 \pm 0.97$ & 1.13 & 14.45 \\
\hline 2 & Base hydrolysis & 1.56 & $94.47 \pm 0.51$ & 0.54 & 4.31 \\
\hline 3 & Oxidative degradation & 1.50 & $77.86 \pm 0.28$ & 0.36 & 21.06 \\
\hline 4 & Thermal degradation & 1.50 & $96.21 \pm 0.38$ & 0.40 & 3.11 \\
\hline 5 & Photo degradation & 1.49 & $97.25 \pm 0.41$ & 0.42 & 2.34 \\
\hline
\end{tabular}
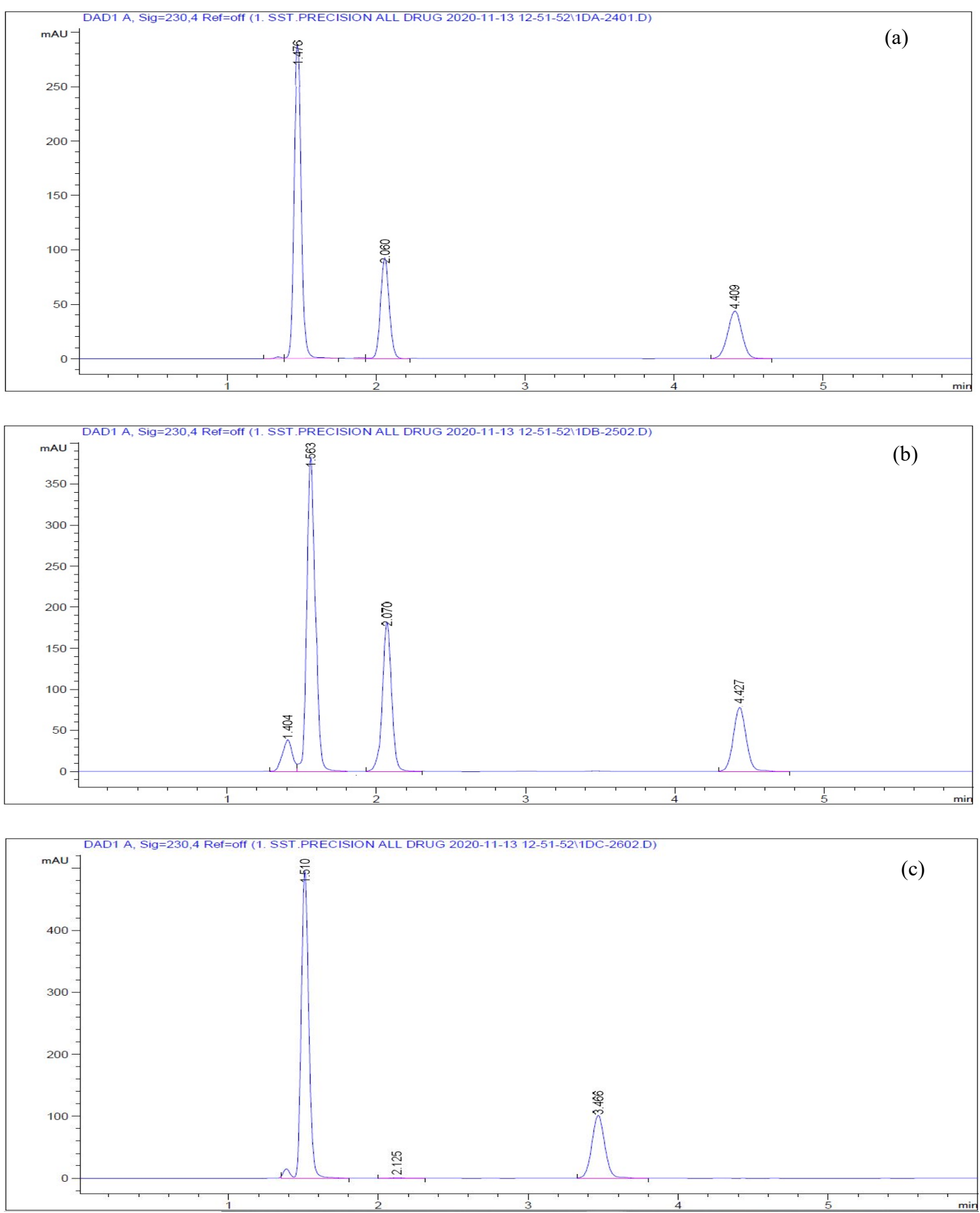
RASĀYAN J. Chem.

Vol. 14 | No. 2 |1384-1393| April - June | 2021
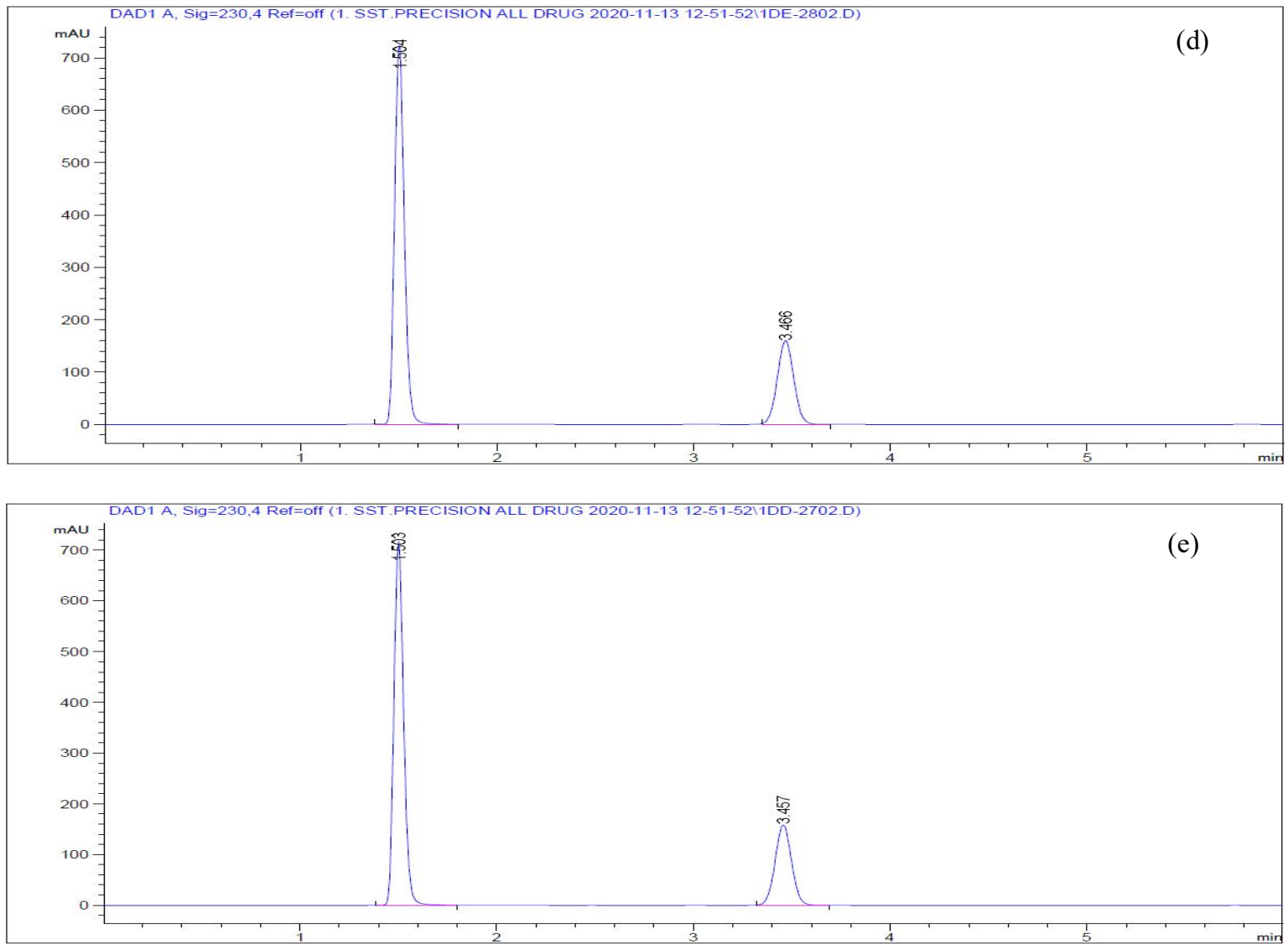

Fig.-5: UHPLC Chromatogram of REMO and MET obtained from Degradation Studies: (a) Acid Hydrolysis (1N $\mathrm{HCl})$; (b) Base Hydrolysis (1N NaOH); (c) Oxidative Degradation $\left(3 \% \mathrm{H}_{2} \mathrm{O}_{2}\right)$; (d) Thermal Degradation $\left(60^{\circ} \mathrm{C}\right)$; (e) Photo Degradation $\left(25^{\circ} \mathrm{C}\right.$ with UV Radiation at $\left.365 \mathrm{~nm}\right)$

\section{CONCLUSION}

To quantify REMO and MET in solid dosage forms simultaneously, the reported optimized chromatographic technique was quick, easy, reliable, and robust. Because the chromatographic program is short, thus more samples can be analyzed in a limited time. This makes our technique highly beneficial in the pharmaceutical industry at a time when multiple products are constantly being developed. All the predefined approval conditions were fulfilled by the method. Both, the bulk sample and formulation samples can be analyzed with this method.

\section{ACKNOWLEDGMENT}

Pramukh Swami Science and H. D. Patel Arts College, Kadi, are gratefully acknowledged by the authors.

\section{REFERENCES}

1. D. J. Magliano, J. W. Sacre, J. L. Harding, E. W. Gregg, P. Z. Zimmet, and J. E. Shaw, Nature Reviews Endocrinology, 16(6), 321(2020), DOI:10.1038/s41574-020-0334-Z

2. M. K. Moon, K. Y. Hur, S. H. Ko, S. O. Park, B. W. Lee, J. H. Kim, S. Y. Rhee, H. J. Kim, K. M. Choi, and N. H. Kim, Korean Journal of Internal Medicine, 32(6), 974(2017), DOI: $10.3904 / \mathrm{kjim} .2017 .354$

3. Lin, Yi, and Zhongjie Sun, The Journal of Endocrinology, 204(1), 1(2010), DOI:10.1677/JOE-090260 .

4. G. Rena, D. G. Hardie, and E. R. Pearson, Diabetologia, 60(9), 1577(2017), DOI:10.1007/s00125$017-4342-z$

5. V. Mohan, A. Mithal, S. R. Joshi, S. R. Aravind, and S. Chowdhury, Drug Design, Development and 
RASĀYAN J. Chem.

Vol. 14 | No. 2 |1384-1393| April - June | 2021

Therapy, 14, 2487(2020), DOI:10.2147/DDDT.S221093

6. K. W. S. Al-Janabi, A. K. Mahmood, and H. M. Luaibi, International Journal of Research in Pharmaceutical Sciences, 11(1), 790(2020), DOI:10.26452/ijrps.v11i1.1896

7. M. Syndrome, B. C. Simes, and G. G. Macgregor, Diabetes, metabolic syndrome and obesity : targets and therapy, 12, 2125(2019), DOI: 10.2147/DMSO.S212003

8. M. Dharmalingam, S. R. Aravind, H. Thacker, S. Paramesh, B. Mohan, M. Chawla, A. Asirvatham, R. Goyal, J. Shembalkar, R. Balamurugan, P. Kadam, H. Alva, R. Kodgule, M. Tandon, S. Vaidyanathan, A. Pendse, R. Gaikwad, S. Katare, S. Suryawanshi, and H. Barkate, Drugs, 80(6), 587(2020), DOI: 10.1007/s40265-020-01285-0

9. V. A. Patel, C. Pandya, A. Pandya, J. Kumbhani, D. Patel, and Z. Patel, International Journal of Technical Innovation in Modern Engineering and Science, 5(03), 296(2019).

10. K. Neelima and Y. R. Prasad, Pharmaceutical Methods, 5(1), 27(2014), DOI:10.5530/phm.2014.1.5

11. K. Chaudhari, J. Wang, Y. Xu, A. Winters, L. Wang, X. Dong, E. Y. Cheng, R. Liu, and S. H. Yang, PLoS One, 15(6), 1(2020), DOI:10.1371/journal.pone.0234571

12. I. Ali, H. Aboul-Enein, and V. Gupta, Combinatorial Chemistry and High Throughput Screening, 10(7), 611(2007), DOI: 10.2174/138620707782152380

13. R. H. Majithia, D. A. Khodadiya, and V. B. Patel, Heliyon, 6(5), e03855(2020), DOI: 10.1016/j.heliyon.2020.e03855

14. C. Varaprasad, M. Asif, and K. Ramakrishna, Rasayan Journal of Chemistry, 8(4), 426(2015).

15. P.S.R.Ch.N.P. Varma D, A. Lakshmana Rao, and S.C. Dinda, Rasayan Journal of Chemistry, 5(3), 269(2012).

16. G. J. Baranwal, S. Upadhyay, A. C. Tripathi, and S. K. Saraf, Rasayan Journal of Chemistry, 8(3), 287(2015).

17. S. Edla and B. Syama Sundhar, Rasayan Journal of Chemistry, 7(1), 55(2014).

18. R. Pravin Cumar, M. Vasudevan, and Deecaraman, Rasayan Journal of Chemistry, 5(2), 137(2012).

19. N. Antonopoulos, G. Machairas, G. Migias, A. Vonaparti, V. Brakoulia, C. Pistos, D. Gennimata and I. Panderi, Molecules, 23(7), 1 (2018), DOI:10.3390/molecules23071548

20. D. Mohamed, M. S. Elshahed, T. Nasr, N. Aboutaleb, and O. Zakaria, BMC Chemistry, 13(3), 1(2019), DOI: 10.1186/s13065-019-0597-4

21. M. K. Munde, N. S. Kulkarni, R. H. Khiste, and D. B. Sen, Research Journal of Pharmacy and Technology, 13(3), 1236(2020), DOI:10.5958/0974-360X.2020.00228.0

22. M. Attimarad, R. E. Elgack Elgorashe, R. Subramaniam, M. M. Islam, K. N. Venugopala, S. Nagaraja, and A. A. Balgoname, Separations, 7(4), 1(2020), DOI:10.3390/separations7040059

23. J. F. Sigafoos, G. D. Bowers, S. Castellino, A. G. Culp, D. S. Wagner, M. J. Reese, J. E. Humphreys, E. K. Hussey, R. L. O'Connor Semmes, A. Kapur, W. Tao, R. L. Dobbins, and J. W. Polli, Drug Metabolism and Disposition, 40(11), 2090(2012), DOI:10.1124/dmd.112.047258

24. M. TAMMISETTY, B. R. CHALLA, and S. B. PUTTAGUNTA, Turkish Journal of Pharmaceutical Sciences, 0(0), 0(2020), DOI:10.4274/tjps.galenos.2020.39699

25. ICH Q2 (R1): Validation of Analytical Procedures: Text and Methodology, November 2005.

[RJC-6295/2020] 